\title{
Periodic Table of Electronic Elements: Application and future simulation \#
}

\author{
Gabriel Luna-Sandoval *1 ${ }^{1}$, Luis Espinoza, Sergio Félix, Martín Santacruz-Tirado, Eusebio Jiménez- \\ López
}

\begin{abstract}
This paper presents an analogic case of a representative Periodic Table of Elements as we know it but with another specific use. The new Periodic Table of Electronics Elements (PTEE) presents in a friendly perspective all electronic elements in order to assimilate better, it should be used in all education institutes where electronics is taught. Also can be transform this new PTEE to be used as a simulator linked all elements to a database showing the technical characteristics of the selected electronic element and its applications. PTEE is being tested in some education subjects where basic electronics are taught with a positive results.
\end{abstract}

Keywords: Electronic, table, elements, simulation, application.

\section{Introduction}

The periodic table of elements (PTE) is a tabular arrangement of the chemical elements, organized on the basis of their atomic numbers, electron configurations, and recurring chemical properties. Elements are presented in order of increasing atomic number. The standard form of the table consists of a grid of elements laid out in 18 columns and 7 rows, with a double row of elements below that. The table can also be deconstructed into four rectangular blocks: the s-block to the left, the p-block to the right, the d-block in the middle, and the f-block below that.

The rows of the table are called periods; the columns are called groups, with some of these having names such as halogens or noble gases. Since, by definition, a periodic table incorporates recurring trends, any such table can be used to derive relationships between the properties of the elements and predict the properties of new, yet to be discovered or synthesized, elements. As a result, a periodic table provides a useful framework for analyzing chemical behaviour, and such tables are widely used in chemistry and other sciences.

Although precursors exist, Dmitri Mendeleev is generally credited with the publication, in 1869, of the first widely recognized periodic table. He developed his table to illustrate periodic trends in the properties of the then-known elements. Mendeleev also predicted some properties of then-unknown elements that would be expected to fill gaps in this table. Most of his predictions were proved correct when the elements in question were subsequently discovered. Mendeleev's periodic table has since been expanded and refined with the discovery or synthesis of further new elements and the development of new theoretical models to explain chemical behavior.

All elements from atomic numbers 1 (hydrogen) to 118 (ununoctium) have been discovered or reportedly synthesized,

\footnotetext{
${ }^{1}$ Universidad Estatal de Sonora, Mexico.

* Corresponding Author: Email: gabriel.luna@ues.mx

\# This paper has been presented at the International Conference on

Advanced Technology\&Sciences (ICAT'14) held in Antalya (Turkey),

August 12-15, 2014.
}

with elements $113,115,117$ and 118 having yet to be confirmed. The first 98 elements exist naturally although some are found only in trace amounts and were initially discovered by synthesis in laboratories. Elements with atomic numbers from 99 to 118 have only been synthesized, or claimed to be so, in laboratories. Production of elements having higher atomic numbers is being pursued, with the question of how the periodic table may need to be modified to accommodate any such additions being a matter of ongoing debate. Numerous synthetic radionuclides of naturally occurring elements have also been produced in laboratories.

Now, making an analogy this paper presents the periodic table of electronic elements which was born from the idea of professor Luis Espinoza in 2007, considering that the current educational programs has not the range of a technician requirements like an electronic repairman in the manufacturing sector. With this experiences the professors are working with students to strengthening the concepts of each electronic component and its performance when different electronic elements are connected together.

We find that a simple and easy tool (PTEE) that shows and strengthen the concepts of each electronic component and its interaction with others components.

\section{Periodic table of electronics elements}

Like periodic table of elements, in the PTEE the elements are presented in order of increasing a symbolic element number. As PTE, the standard form of the PTEE consists of a grid of elements laid out in 18 columns and 7 rows, with a double row of elements below that.

The table can also be deconstructed into four rectangular blocks: the s-block to the left, the p-block to the right, the d-block in the middle, and the f-block below that.

In the PTEE rows of the table are called periods; the columns are called groups, with some of these having names such as resistances or diodes, as shown in Fig. 1 


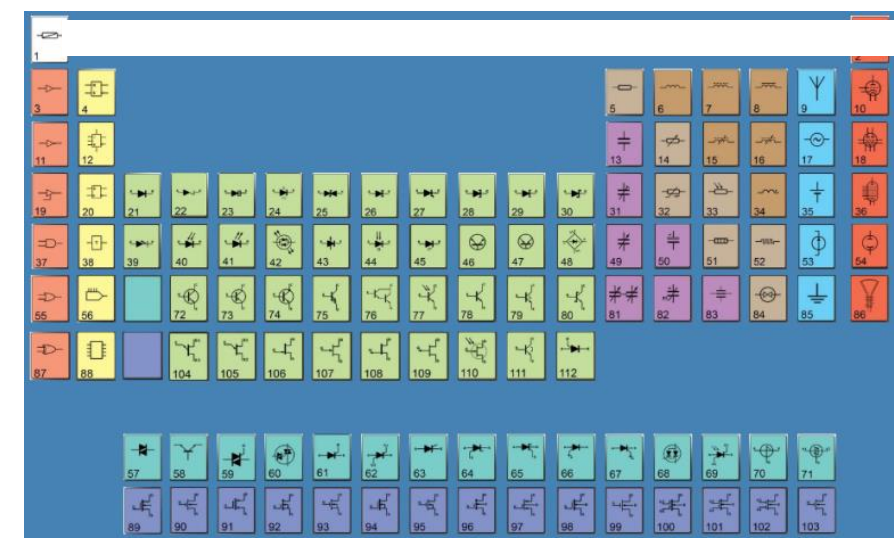

Figure 1. Periodic table of electronic elements.

Also it will be added Table 1 in the PTEE to identify the groups of the electronic elements with colours of the rows and columns.

Table 1. Groups with colours of the Electronic elements in the PTEE.

\begin{tabular}{|c|c|c|c|c|}
\hline $\begin{array}{c}\text { Puertas } \\
\text { Lógicas }\end{array}$ & $\begin{array}{c}\text { Circuitos } \\
\text { Lógicos }\end{array}$ & $\begin{array}{c}\text { Diodos } \\
\text { Transistore } \\
\mathrm{s}\end{array}$ & $\begin{array}{c}\text { Diac, Triac } \\
\text { Tristor }\end{array}$ & Mosfet \\
\hline $\begin{array}{c}\text { Condensadore } \\
\mathrm{s}\end{array}$ & $\begin{array}{c}\text { Resistencia } \\
\mathrm{s}\end{array}$ & Bobinas & $\begin{array}{c}\text { Generadore } \\
\mathrm{s}\end{array}$ & $\begin{array}{c}\text { Válvula } \\
\mathrm{s}\end{array}$ \\
\hline
\end{tabular}

The entire list of electronic elements it will be added to the PTEE, as summarized in Table 2.

Table 2. Some corresponding numbers of some Electronic elements in the PTEE.

\begin{tabular}{|c|c|}
\hline 1 & Fusible \\
\hline 2 & Diodo \\
\hline 3 & Buffer \\
\hline 4 & Bascula R-S \\
\hline 5 & Resistencia \\
\hline 6 & Bobina Inductor \\
\hline 7 & Bobina Núcleo De Fierro \\
\hline 8 & Bobina Núcleo De Fe-Si \\
\hline 9 & Antena \\
\hline 10 & Triodo \\
\hline 11 & Inversor \\
\hline 12 & Bascula J-K \\
\hline 13 & Capacitor General \\
\hline 14 & Resistencia Variable \\
\hline 15 & Bobina Ajustable \\
\hline 16 & Bobina Variable \\
\hline 17 & Generador De Corriente Alterna \\
\hline 18 & Triodo Doble \\
\hline 19 & Buffer Triestado \\
\hline 20 & Bascula D \\
\hline 21 & Diodo Rectificador \\
\hline
\end{tabular}

Table 2, Continuation. Some corresponding numbers of some Electronic elements in the PTEE

\begin{tabular}{|c|c|}
\hline 22 & Diodo Zenner \\
\hline 23 & Diodo Varicap \\
\hline 24 & Diodo Gun Impatt \\
\hline 25 & Diodo Schottky \\
\hline 26 & Diodo De Corriente Constante \\
\hline 27 & Diodo De Recuperacion Instantanea Snap \\
\hline 28 & Diodo Tunel \\
\hline 29 & Diodo Rectificador Tunel \\
\hline 30 & Diodo Schottky \\
\hline 31 & Capacitor Ajustable \\
\hline 32 & Termistor (Ntc) Coeficiente De Temp. Neg \\
\hline 33 & Ldr Fotoresistor \\
\hline 34 & Polaridad De Bobinado \\
\hline 35 & Generador De Tension Continua \\
\hline 36 & Octodo \\
\hline 37 & Compuerta And \\
\hline 38 & Flip Flop T \\
\hline 39 & Diodo Pin \\
\hline 40 & Fotodiodo \\
\hline 41 & Diodo Emisor De Luz "Led" \\
\hline 42 & Diodo Bicolor Polaridad Dual \\
\hline 43 & Diodo Laser \\
\hline 44 & Diodo Magnetico \\
\hline 45 & Diodo Sensible A La Temperatura \\
\hline 46 & Diodo De Ruptura Bidireccional Pnp \\
\hline 47 & Diodo De Ruptura Bidireccional Npn \\
\hline 48 & Puente Rectificador \\
\hline 49 & Capacitor Variable \\
\hline 50 & Capacitor Electrolitico \\
\hline 51 & Elemento De Calefaccion \\
\hline 52 & Resistencia No Reactiva \\
\hline 53 & Generador De Corriente Continua \\
\hline 54 & Celula Fotoelectrica \\
\hline 55 & Compuerta Or \\
\hline 56 & Convertidor Analogico Digital "Dac" \\
\hline 57 & Diac \\
\hline 58 & Trigger Diac \\
\hline 59 & Triac \\
\hline 60 & Ditriac/Quadrac \\
\hline
\end{tabular}


Table 2. Continuation. Some corresponding numbers of some Electronic elements in the PTEE

\begin{tabular}{|c|c|}
\hline 68 & Darlington \\
\hline 69 & Fotoresistor \\
\hline 70 & Sus Silicon Unilateral Swicht \\
\hline 71 & Sbs Silicon Bilateral Swicht \\
\hline 72 & Transistor Npn \\
\hline 73 & Transistor Pnp \\
\hline 74 & Transistor Npn Colector Unido A La \\
Cubierta
\end{tabular}

\section{Interactive PTEE}

The next premise and innovation to the PTEE is to apply an interactive educational and simulation way. Using an executable file containing 4 links: the PTEE, electronic Laws, formulas and resistance colour codes it is giving a new teaching tool to the professor and a new learning tool to the student, as shown in Fig. 2 .

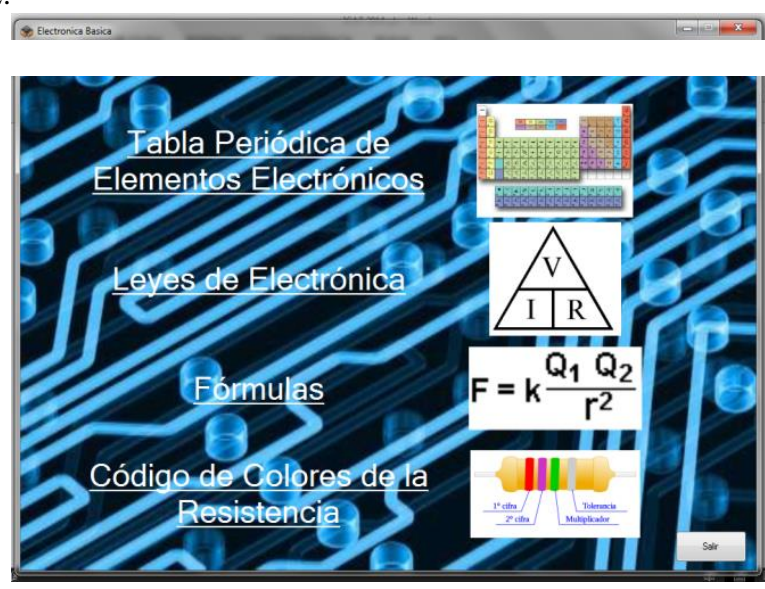

Figure 2. Executable file that contains the PTEE, electronics Laws, formulas and resistance colour codes
As When the students need to reinforce the knowledge in any content of the 4 links from the executable file, they should click on the link to open a windows that shows all information about the topic selected.

Clicking the link, the teacher and student will find the concept and application of the electronic element, as shown in Fig. 3.

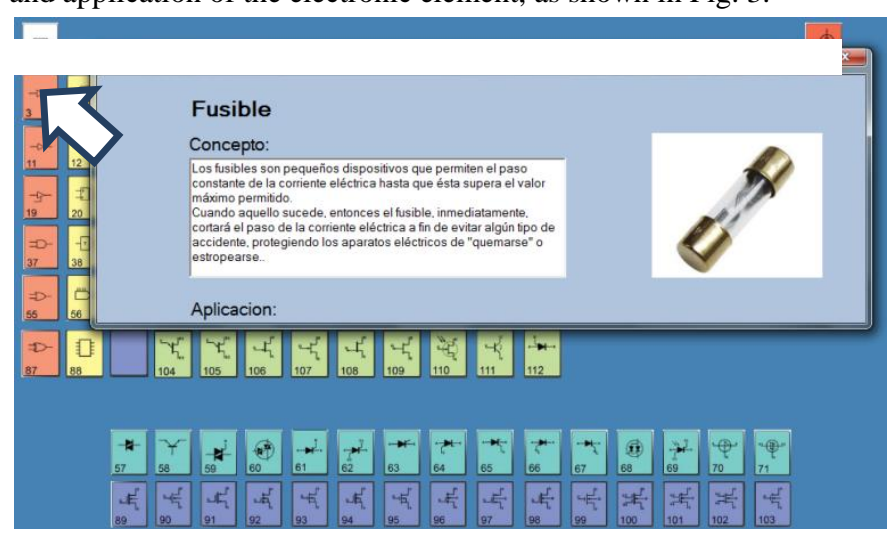

Figure 3. Interactive periodic table of electronic elements.

\section{Conclusion}

In The premise of the periodic table of electronic elements has been well received by students of electronic in college. This useful teaching tool are contributing to enhance the knowledge in students and an easy way to teachers to teach in the classroom. The interest and learning of the students are reflected in their final excellent scores unlike other semesters without the use of the PTEE. The innovative PTEE should be used in all educational institutes around the world where electronics subjects are teaching. Finishing the interactive PTEE the results will be published in other paper presenting how students and teachers was benefited with this educational tool. future.

\section{Acknowledgements}

The authors of this research are grateful to all educational institutes who supports the entire project from its beginnings. Especially to Universidad Estatal de Sonora and to CBTis 33.

\section{References}

[1] S. M. Eric R. Scerri, How Good Is the Quantum Mechanical Explanation of the Periodic System? DOI: 10.1142/9781848164260_0005

[2] Eric R. Scerri, John Worrall, Prediction and the Periodic Table. DOI: 10.1142/9781848164260_0006

[3] Eric Scerri, The Role of Triads in the Evolution of the Periodic Table: Past and Present. DOI: 10.1142/9781848164260_0009

[4] Eric R. Scerri, The Past and Future of the Periodic Table. DOI: 10.1142/9781848164260_0010

[5] A. Dumoulin, M. John, P. McEvoy, M.J. Ammann, "Optimised Tapered-Slot antenna for Real Time Location Systems," Communications and Radio Sciences Research Colloquium, Royal Irish Academy, Dublin, 28 March, 2012.

[6] G. Szczepkowski, R. Farrell, "10 GHZ, Class-B, 0.5 V, 130nm CMOS Oscillator Design Using Open-Loop Technique", Royal Irish Academy Colloquium on Communication and Radio Science, March, 2012.

[7] D. Rafique and A. D. Ellis, "Nonlinearity Compensation via Spectral Inversion and Digital Back-Propagation: A 
Practical Approach", Optical Fiber Communication Conference and Exposition and the National Fiber Optic Engineers Conference (OFC/NFOEC), 2012, paper OM3A. March, 2012.

[8] Punch, J., 2012, "Thermal Challenges in Photonic Integrated Circuits", (Keynote), Proceedings of EuroSIME 2012: Thermal, Mechanical and Multi-physics Simulation and Experiments in Micro-electronics and Micro[9] systems, Lisbon, Portugal, April 16-18, 2012.

[10] Carlo Galiotto, Nicola Marchetti, Linda Doyle, "Flexible Spectrum Sharing and Interference Coordination for Low Power Nodes in Heterogeneous Networks“, 2012 IEEE 76th Vehicular Technology Conference: Québec City, Canada, VTC2012-Fall 3-6 September 2012.

[11] William Cotter, Padraic Morrissey, David Goulding, Yang Hua, Brendan Roycroft, James O'Callaghan, Brian Corbett, Tyndall National Institute, Cork and Frank H. Peters, University College Cork, "Coherent Comb Generation using Integrated Slotted Fabry-Perot Semiconductor Lasers", IPC 2012, Burlingame, California, 23rd - 27th September, 2012.

[12] D. Rafique, A. D. Ellis, "Scaling the Advantages of Intrachannel Nonlinearity Compensation in Future Flexible Optical Networks", 38th European Conference on Optical Communications (ECOC 2012), paper P4.18, September, 2012.

[13] Xu, C., Wright, B., Demirkan, K., Opila, R.L., Hannigan, K., Reid, M., Punch, Collins, M.N., Reents, W.D. Jr., Fleming, D.A., Franey, J.P., Derkits, G.E. and Ahern, P., 2012, "Corrosion Mechanisms of Lead-Free CB Surface Finishes in Corrosive Environments", Proceedings of the SMTA International Conference, Orlando, FA, USA, Oct 14-18, 2012.

[14] Weiss, Martin B.H. and Krishnamurthy, Prashant and Pelechrinis, Konstantinos and Doyle, Linda E. "When is electromagnetic spectrum fungible?" In proceedings of the IEEE DySPAN (Dynamic Spectrum Access Networks), October 2012, Bellevue, Washington, USA pp12.

[15] Abraham Loutridis, Matthias John, Giuseppe Ruvio and Max J. Ammann, "A 2.45/5.8 GHz Folded Monopole Antenna for WLAN Application," Loughborough Antennas \& Propagat, Loughborough, UK., 12th \& 13th November 2012.

[16] M. J. Ammann. X.L. Bao and A. Narbudowicz (INVITED), "Circularly Polarized Terminal Antennas for Emerging Wireless Systems," Loughborough Antennas \& Propagat, Loughborough UK., 12th \& 13th November 2012.

[17] Y. Xiao, T. Forde, I. Macaluso, L. E. Doyle, and L. A. DaSilva, "Spatial Spectrum Sharing-based Carrier
Aggregation for Heterogeneous Networks," IEEE Globecom, Anaheim, CA, December 3-7, 2012.

[18] T. Forde and L. Doyle, "Dynamic Block-Edge Masks (BEMs) for Dynamic Specturm Emission Masks (SEMs)“, IEEE DySPAN 2010 Singapore, 6-9 April, 2010.

[19] Paul Sutton, Baris Ozgul, Linda Doyle, Irene Macaluso, "OFDM Pulse-Shaped Waveforms for Dynamic Spectrum Access Networks", Fourth IEEE International Symposium on New Frontiers in Dynamic Spectrum Access Networks 2010 (DySPAN 2010) Singapore, 6-9 April, 2010.

[20] L. E. Doyle, P. Sutton, K. Nolan, B. Ozgul, J. Lotze, T. Rondeau, S. Fahmy, H. Lahlou, and L. A. DaSilva,"Experiences from the Iris testbed in dynamic spectrum access and cognitive radio experimentation," IEEE Symposia on New Frontiers in Dynamic Spectrum Access Networks (DySPAN), Singapore, 6-9 April, 2010.

[21] Paulo MARQUES, Jonathan RODRIGUEZ, Linda DOYLE, Tim FORDE, 3Hervé AIACHE, Jürgen LAUTERJUNG, Álvaro GOMES, Stavros STAVROU, Hanna BOGUCKA, Jerzy KUBASIK, George KORMENTZAS, Georg SCHUBERTH, "The COGEU FP7 project: Cognitive Radio Systems for Efficient Sharing of TV White Spaces in European Context", ICT-SUMMIT 2010. [Future Network and Mobile Summit 2010 (IEEE sponsored), ISBN: 978-1-905824-16-8, Florence, Italy, June 16-18, 2010.]

[22] K. Shi, F. Smyth, D. Reid, R. Maher, B. Roycroft, B. Corbett, F. H. Peters, P. Anandarajah, L. P. Barry, "SelfCoherent Optical Transmission Using a Narrow Linewidth Tunable Slotted Fabry-Perot Laser", Paper JWA35, Proceedings of Conference on Optical Fiber Telecommunications (OFC2010), San Diego, March 22nd26th, 2010

[23] K. Shi, F. Smyth, D. Reid, B. Roycroft, B. Corbett, J.H. Song, P. O'Brien, F. H. Peters, L. P. Barry, "Characterization of a Novel Three-Section Tunable Slotted Fabry Perot Laser", Paper OWU3, Proceedings of Conference on Optical Fiber Telecommunications (OFC2010), San Diego, March 22nd-26th, 2010

[24] Kelly, G., Punch, J. and Goyal, S., 2006, "The Dynamics of a Small-Scale Portable Electronics Device Under Impact Stimuli", the American Society of Mechanical Engineers International Mechanical Engineering Congress and Exposition, IMECE2006-14371, Chicago, IL, 5 - 10 November 2006

[25] Sheehy, M., Punch, J. and Goyal, S., 2006, "The Response of a Miniature Scale Cantilever Beam to High-G Impact Stimuli", accepted for presentation at the American Society of Mechanical Engineers International Mechanical Engineering Congress and Exposition, IMECE2006-14351, Chicago, IL, 5 - 10 November 2006 